\title{
Quality of governance as measured by World Bank indicators for the region of south-east Europe
}

\begin{abstract}
The comparative international measurement of state governance or corruption did not exist until twenty years ago. In that time, the number of empirical investigations concerning state governance has started to increase rapidly. The most famous basis of good governance indicators is based on the lengthy research programme of the World Bank and its research section. This includes six key dimensions of governance: freedom of expression and responsibility; political stability and the non-existence of violence; government efficiency; legislative quality; the rule of law; and the control of corruption. The World Bank publishes the results of its research once a year, covering 185 countries all over the world.
\end{abstract}

Keywords: good governance indicators, World Bank, economic growth.

\section{Introduction}

State governance is the essential criterion behind the quality and functioning of each political/administrative system and it represents a very important factor in economic development and prosperity.

There is an equivalent link, in terms of general EU goals, between state governance, democratisation and development. Separate agreements and the Commission's white paper on Governance in the European Union define it. That is the reason why the building of institutional capacities, especially in the sphere of good state governance and the rule of law, represents one of six priorities of EU development policy that applies to support for EU programmes in development countries.

The structure and quality of state governance are important determinants of social cohesion or conflict, the success or failure of economic development and the protection or degradation of the environment, just as much as is the respect for, or violation of, human rights and basic freedoms. The international community accepts this relationship in general and it demonstrates the importance of state governance for development.

\section{State governance and quality elements of state governance}

State governance could be considered as the manner in which the state uses its authority to manage its economic and human resources with the objective of the development of the country. This is one of the definitions of the World Bank, but there is also a more complex definition which sees state governance as: 
a) the process of electing, controlling and replacing the government

b) the capability of the government to manage its resources efficiently and to implement appropriate policies

c) the respect by citizens and the state towards the institutions which regulate the economic and social relationships between them.

The existence of certain rules and institutions that create a predictable and transparent framework for business and investment is necessary for the efficient functioning of the state, and it also stimulates economic growth. One of the important activities of the state is to establish a legal framework for the performance of all economic activities within which companies and individuals may establish mutual economic relations. The state regulates economic activities in order to protect employees, consumers and the environment, as well as to prevent anti-competitive and discriminatory behaviour. State administration is one of the most important public welfares since everyone benefits from a better, more efficient and more responsible state (Stiglitz, 2004).

It is difficult to measure state governance reliably. In spite of that, the number of databases increases every day. These indicators are mostly based on the subjective perceptions of commercial agencies for risk assessment (BERI, PRS); NGOs (Freedom House, Heritage Foundation, World Economic Forum, Transparency International); and multilateral organisations (World Bank, European Bank for Reconstruction and Development, UN Development Programme). These indicators are based on estimations and, as a result, they need to be considered carefully.

The most famous research study on the topic of the quality of state governance is the one based on the lengthy research programmes of the World Bank Institute and implemented by experts from the World Bank. It was published as the series of studies called Governance Matters.

According to the World Bank experts Daniel Kaufmann, Aart Kraay and Pablo Zoido-Lobaton, ${ }^{1}$ state governance covers - as indicated in the complex definition above - the process of electing, controlling and replacing governments; the capacity of the government to formulate and implement appropriate policies; and the respect of citizens and the state towards institutions. Based on this definition, they have formulated the following elements for the estimation of state governance: the potential for the participation of citizens in the election of the government and the responsibility of policy-makers; political stability; state efficiency; legislative quality (administrative obstacles); the rule of law; and the control of corruption. These elements are the ones usually referred to in the literature.

According to the UNDP, it is possible to assess good state governance on the basis of certain characteristics, including participation (freedom of alliance and expression, organised civil society); promotion of the rule of law (a legal framework implemented by independent courts and non-corrupt police, secure property rights, etc.); transparency; and the understanding of the needs of citizens. State consensus in making decisions; equality and the participation of all citizens in making decisions; effi-

1 Kaufmann, Kraay and Zoido-Lobaton are the authors of the first study in the Governance Matters series. 
ciency in satisfying the needs of society, using the available resources in a sustainable way; and the responsibility of government and the private sector towards the public which is influenced by their decisions are some of the other characteristics.

According to Huther and Shah, the quality of state governance grows where the public service responds to citizens in such a way that it satisfies their interests, because it results in a higher responsibility of the public sector. They measured the quality of state governance using the following elements: political stability; political freedom; efficiency of the courts; efficiency of public administration; level of corruption; equality in the distribution of revenues; and macroeconomic management (Huther and Shah, 1998).

Campos believes that state governance has five key institutional components that are mutually connected:

a) executive authority

b) public administration

c) rule of law

d) policy making

e) civil society.

Some conditions have to be fulfilled before a particular state governance can be considered as a good one. These conditions mean that the executive authority has to be responsible for its acts; the state administration has to be efficient and capable of adjusting to society's needs; an appropriate legal framework has to exist; politics must be characterised by openness and transparency; and civil society must be developed and capable of participating in state functions (Campos, 2000).

Reform of the European state administration is one of the EU's strategic goals. The European Commission adopted its white paper on Governance in the European Union $^{2}$ in 2001. This proposed a more open process of decision-making in order that more people and organisations could take part in the making of decisions. European Union policy ${ }^{3}$ frequently emphasises the importance of democracy and the rule of $\mathrm{law}^{4}$ in member states and their implementation at each level - global, European, national, regional and local. The European Commission recommends the implementation of the following principles:

1. transparency and open communication with the public

2. the more intensive participation of citizens in policy-making

3. a higher level of responsibility of policy-makers

4. efficiency in policy implementation

5. harmonisation of all political measures and authority levels in order to achieve consistency.

2 Commission of the European Communities (2001).

3 Apart from the European Commission, the participation of other EU institutions, central governments, regions, municipalities and civil society in both present and future member states is needed for the implementation of reforms.

4 The rule of law and democracy represent the first of the Copenhagen criteria and, at the same time, these are elements in the assessment of the quality of state administration. 
Kaufmann, Kraay and Zoido-Lobaton, the experts of the World Bank Institute, defined a methodology for measuring the aggregate indicators of state governance (Massimo Mastruzzi joined them later). They published the first study named Governance Matters (Kaufmann, Kraay and Zoido-Lobaton, 1999) in 1999 (covering figures for 1997/1998). Six studies have been published thus far and the last one, Governance Matters VI: Aggregate and Individual Governance Indicators for 1996-2006, was published in July 2007. These research studies have resulted in the assessment of the aggregate indicators of state governance, measuring six dimensions of state governance:

1. freedom of speech and the responsibility of policy-makers

2. political stability and the non-existence of violence

3. government efficiency

4. legislative quality (administrative obstacles)

5. the rule of law

6. control of corruption.

In the period between 1996 and 2002, global indicators of state governance were measured every two years while data have been published every year since 2002 .

Taking into consideration the definition of the World Bank that state governance is 'the set of legal acts and institutions in a certain country', these indicators cover and reflect the following dimensions:

1. political dimension: more precisely, the process under which authority is elected, controlled and replaced; measurable indicators are freedom of expression, responsibility and political stability

2. economic dimension: more precisely, the capability of the government to manage its resources in an efficient manner and to implement appropriate policies; measurable indicators are government efficiency and legislative quality

3. institutional dimension: more precisely, respect towards the institutions which regulate economic and social relations between the state and its citizens; measurable indicators are rule of law and control of corruption.

\section{State governance and economic growth}

Many modern researchers emphasise the link between state governance and economic growth.

In order to explain the differences between countries, Hall and Jones created an index of social infrastructure consisting of two mutually-supporting criteria focusing on the economic ambience for investment (Hall and Jones, 1999). The first criterion is the index of state policies that stimulate production; and the second is the allotment of years when the country was open for international trade in the period since 1950. In this research study, they used subjective criteria of state governance (social infrastructure) such as the rule of law, corruption, legislative quality, expropriation risk and non-recognition by the state, carrying out an analysis for 127 countries. $^{5}$

5 The concept of the index is that 0 represents the worst and 1 the best infrastructure. They used GDP from 1988 in the research, and the index represented the standard for the 1986-1995 period in which each variable had the same weight. 
They examined the achieved level of GDP, which is a better indicator of the longterm economic successfulness of a certain country in the context of prosperity (the consumption of goods and services) than the growth rate and, because of this, they believed that the state infrastructure changes too slowly to influence the growth rate in the short-term. Hall and Jones did not mention state governance but wrote about it as social infrastructure.

In contrast, Huther and Shaha created an index of the quality of state governance, which covered a number of dimensions such as: citizen participation (political freedom and political stability); government orientation (the efficiency of courts, the efficiency of the bureaucracy and corruption); societal development (equal distribution of revenues and human development); and economic governance (the independence of the central bank, debt as a percentage of GDP and international openness). The purpose of this index of the quality of state governance was to show the capability of the government to provide political transparency, efficient public services, improvements to the health and prosperity of all citizens and an appropriate environment in which stable economic growth could take place (Huther and Shah, 1998).

The experts of the World Bank, Kaufmann and Kraay, divided the strong positive link between state governance and GDP into two parts (Kaufmann and Kraay, 2002). The first shows that better state governance means higher per capita GDP; and the second that there is a weak, even negative, causal effect between GDP and state administration. These results are valid over a long period and do not mean that countries with a high growth rate over a short period have poor state governance. They underline that the never-ending circle in which rich countries have better opportunities to improve governance can not be over-emphasised; in fact, countries with a higher GDP need other interventions in order to improve governance, not only their relative wealth.

In other words, good state governance is not a 'luxurious wealth' that only rich countries can afford. They explain the negative influence of GDP per capita on state governance as the influence of elites and the private sector on the state (state cap-

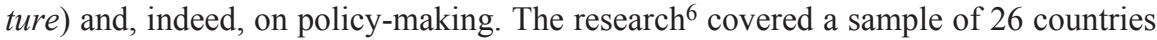
in Latin America and the Caribbean. They only indicator used in assessing state governance was the rule of law, but they emphasised that its correlation with corruption and government efficiency is very high. The improvement of the indicator of the rule of law by one standard deviation increases GDP at least three times over a very long period. This means that even small advances in the rule of law result in the improvement of economic success in the long run. Statistically explained, the improvement of this one indicator, the rule of law, by one standard deviation (or one level of detachment) leads to an increase in present revenues from $\$ 1000$ per capita to $\$ 3000$ per capita in the long run. This improvement was defined as the 'development dividend'.

6 They used indicators of state governance for the 2000-2001 period and the variable was a logarithm of GDP per capita from 1995 presented in PPP (purchasing power parity) in US dollars from 1985. 
The positive correlation between rapid increases in growth and good state governance indicates that it is the latter that improves economic efficiency, not vice versa.

\section{World Bank indicators and assessment for south-east Europe}

Good state governance contributes to economic development, while bad governance prevents and slows economic development. Bad decision-making is a reason for inadequate state governance and is often reflected in corrupt government and a lack of capacity for the efficient management of the state administration. State governance could be improved by investing in other factors (for example, education, health, etc), that encourage the accumulation of human capital in general development.

Good and efficient institutions and a lack of administrative capacity are some of the major remarks of international institutions concerning the region of south-east Europe. European institutions (such as the European Commission) are especially critical regarding the quality of institutions.

The region of south-east Europe covers states in the process of transition which have low economic strength, mostly also with lower revenues. ${ }^{7}$ The region covers nine countries: Albania, Bosnia and Herzegovina, Bulgaria, Montenegro, Croatia, Macedonia, Moldova, Romania and Serbia. Looking at the macroeconomic indicators for the south-east Europe region, it is noticeable that the growth rate of GDP is over $5 \%$, inflation is under control, the unemployment rate is relatively high and the inflow of foreign direct investment is frequently increasing. The main characteristics of the region are a high trade deficit, low exports and weak intra-regional trade and investment. Examining certain policies, especially those related to state governance (legislation reform, anti-corruption, competition), the achievements of the region are not particularly impressive.

The process of the accession of Bulgaria and Romania was speeded up with the reform process. Reforms in the region occur at different times and in different phases, depending on the situation in the country: Bulgaria, Romania, Montenegro, Serbia and Croatia are leading reformers in the region, while other countries are lagging.

\section{Freedom of expression and the responsibility of policy-makers}

Table 1 provides the results (score and percentage rating) that the countries of southeast Europe achieved in the framework of freedom of expression and the responsibility of policy-makers.

7 The World Development Report classifies states on the basis of their level of per capita Gross National Income, such that there is the following classification for revenues: low revenue (below $\$ 875$ ), medium revenue (from $\$ 875$ to $\$ 10725$ ) and high revenue (above $\$ 10725$ ); medium revenue is also sub-divided: lower medium revenue consists of sums up to $\$ 3465$; and above that figure, upper medium revenue. 
Table 1 - Freedom of expression and responsibility of policy-makers

\begin{tabular}{|l|c|c|c|c|c|c|}
\hline \multirow{2}{*}{} & \multicolumn{2}{|c|}{1996} & \multicolumn{2}{c|}{ 2002 } & \multicolumn{2}{c|}{ 2006 } \\
\cline { 2 - 7 } & Score* & Rating** & Score* & Rating** & Score* & Rating** $^{*}$ \\
\hline Albania & -0.49 & 32.5 & -0.09 & 47.1 & -0.01 & 50.0 \\
\hline $\begin{array}{l}\text { Bosnia and } \\
\text { Herzegovina }\end{array}$ & -0.38 & 35.4 & -0.25 & 43.3 & 0.18 & 54.8 \\
\hline Bulgaria & 0.09 & 51.2 & 0.61 & 65.9 & 0.56 & 65.4 \\
\hline Croatia & -0.28 & 38.8 & 0.56 & 63.9 & 0.42 & 61.1 \\
\hline Macedonia & -0.12 & 45.9 & -0.30 & 41.8 & 0.07 & 52.9 \\
\hline Moldova & -0.06 & 47.8 & -0.52 & 34.1 & -0.48 & 32.7 \\
\hline Romania & 0.18 & 54.5 & 0.49 & 62.0 & 0.43 & 61.5 \\
\hline Serbia & -1.38 & 11.0 & -0.14 & 45.2 & 0.05 & 51.4 \\
\hline
\end{tabular}

* Note: 'Score' varies in range from -2.5 to 2.5; higher numbers mean a better result. The result attained is the weighted average of the observed results for each country recounted in the common unit. Weights are proportionate to the accuracy of the data from used sources, and accuracy is dependent on the level of correlation between individual sources.

** 'Rating', or percentage rating, expresses the percentage of countries in the sample (from more than 200 countries) which the particular country is assessed as better than in some dimension of state administration; improvements over time are thus reflected in an increase in the figures.

All countries in the region recorded growth trends in this indicator during the period of observation except Moldova, where the situation worsened (from -0.06 to -0.48). The new EU members have especially good results: Bulgaria had a figure of $65.4 \%$ (meaning that the rating is better than in $65.4 \%$ of other countries) and Romania $61.5 \%$. Croatia recorded a figure of $61.1 \%$, Bosnia and Herzegovina $54.8 \%$ and Macedonia $52.9 \%$.

Following discrete changes in south-east European countries in the 1996-2006 period, it is noticeable that Serbia achieved the biggest improvement in the region concerning the score for freedom of expression and responsibility (1.45): in 1996, it recorded a rating of -1.38 (the lowest score in the region), while in 2006 this had risen to 0.05 . So, Serbia exceeded Albania $(-0.01)$ and Moldova $(-0.48)$. Croatia achieved significant growth for this factor, from -0.28 in 1996 to 0.42 in 2006, while Bosnia and Herzegovina went from -0.38 to 0.18 in this time.

\section{Political stability in south-east Europe region}

The indicator of political stability combines different indicators that measure perceptions about the possibility of destabilisation and the replacement of authority in a nonconstitutional and violent way, i.e. by the use of political violence or terrorism. This indicator also shows the influence of any replacement of the authority on the continuity of policy implementation and the capability of citizens to choose and replace the 
authority in a peaceful way, depending on the state. It can be a democratic state, where authority is chosen in legal elections, or an authoritarian state where authorities are replaced through unrest, rebellion or even revolution.

It is possible to assess political stability based on the division of the political scene and the profile of certain parties. Political instability has a negative impact on economic growth because of the higher risk to investment.

Long-term political instability is a characteristic of the south-east Europe region. The wars of the nineties, which was not that long ago, have had serious consequences. There has been a certain improvement during the last few years: the organising of peaceful and fair elections in all countries; the signing of important regional agreements on trade, energy; etc. Montenegro gained its independence in a referendum. Table 2 provides the results (scores and ratings in percentages) concerning the framework of indicators on political stability in south-east Europe.

Table 2 - Indicators of political stability in south-east Europe

\begin{tabular}{|l|c|c|c|c|c|c|}
\hline \multirow{2}{*}{} & \multicolumn{2}{|c|}{1996} & \multicolumn{2}{c|}{ 2002 } & \multicolumn{2}{c|}{ 2006 } \\
\cline { 2 - 7 } & Score* & Rating** & Score* & Rating** & Score* & Rating** \\
\hline Albania & -0.13 & 39.9 & -0.62 & 27.4 & -0.37 & 33.7 \\
\hline $\begin{array}{l}\text { Bosnia and } \\
\text { Herzegovina }\end{array}$ & -0.50 & 29.3 & -0.67 & 26.4 & -0.52 & 28.4 \\
\hline Bulgaria & -0.22 & 37.0 & 0.48 & 63 & 0.29 & 57.2 \\
\hline Croatia & -0.11 & 40.9 & 0.39 & 59.6 & 0.47 & 62.0 \\
\hline Macedonia & 0.22 & 51.9 & -1.00 & 18.8 & -0.66 & 25.0 \\
\hline Moldova & 0.05 & 45.2 & -0.15 & 42.3 & -0.48 & 29.8 \\
\hline Romania & 0.39 & 56.3 & 0.32 & 56.7 & 0.12 & 50.0 \\
\hline Serbia & -1.12 & 15.4 & -0.75 & 23.1 & -0.69 & 24.5 \\
\hline
\end{tabular}

Source: Kaufmann et al. (2007)

* and **-see Table 1

Looking at the results attained, it is easy to conclude that political stability is not a characteristic of the majority of south-east European countries, which is understandable if we look back at history. Croatia $(0.47)$ was the best-placed country in the region in 2006, while Bulgaria (0.29) was in second place and then Romania (0.12), while other countries had negative results: Serbia -0.69, Macedonia -0.66, Bosnia and Herzegovina -0.52 , Moldova -0.48 and Albania -0.37 .

When we observe the individual development of this segment of the measurement of authority in south-east European countries in the 1996-2006 period, the biggest improvement was recorded in Croatia: its score in 1996 was -0.11 , while in 2006 it was 0.47 (i.e. a growth of 0.58 ). Bulgaria improved its result from -0.22 to 
0.29 (i.e. a growth of 0.51 ). It may have achieved solid growth of 0.43 (from -1.12 to -0.69), but Serbia still has a high negative result for political stability, which thus represents the weakest dimension of state governance out of all the World Bank's six measurable elements. Even so, in 1998 Serbia had the worst score on this factor for the south-east Europe region in the whole decade: -1.95 .

Other countries of the region have seen a deterioration in political stability: Macedonia recorded the biggest reduction, of 0.88 (from 0.22 in 1996 to -0.66 in 2006); while the next lowest position was taken by Moldova (from 0.05 to -0.48 ), Romania (from 0.39 to 0.12 ), Albania (with a change from -0.13 to -0.37 ) and Bosnia and Herzegovina (from -0.50 to -0.52 ).

\section{Government efficiency in the region of south-east Europe}

Government efficiency refers to the quality of public services, the capability of state servants and their level of independence from political pressure, the quality of the bureaucracy, the capability of managers for stable governance without drastic changes in policy and the existence of efficient mechanisms for the employment and training of civil and public servants. The same is true as regards the quality of the formulation and implementation of policies and government reliability.

Employment on the basis of political criteria is present in many countries in transition, resulting in a loss of economic growth because of such rent-seeking behaviour and less investment in human capital by the state administration. The professional integrity of the state administration depends on the impartiality and the professional independence of its services. Arising from a recognition of the need to strengthen impartiality, legal regulations have been made to forbid state servants from participating in the making of decisions which could influence their personal interests.

At the same time, the state is responsible for a professional, impartial and efficient state administration that must comply with the rule of law. The state has to guarantee that its personnel will be of a certain quality and to assure the same standards of quality are delivered right across the entire state administration. In that sense, a wellorganised system of state administration provides the achievement of appropriate standards of professionalism, stability, continuity and quality. Table 3 provides data about the levels of government efficiency in the south-east European region.

Table 3 - Government efficiency in south-east Europe

\begin{tabular}{|l|c|c|c|c|c|c|}
\hline \multirow{2}{*}{} & \multicolumn{2}{|c|}{1996} & \multicolumn{2}{c|}{2002} & \multicolumn{2}{c|}{2006} \\
\cline { 2 - 7 } & Score* & Rating** & Score* & Rating** & Score* & Rating** \\
\hline Albania & -0.11 & 56.4 & -0.59 & 31.3 & -0.42 & 38.4 \\
\hline $\begin{array}{l}\text { Bosnia and } \\
\text { Herzegovina }\end{array}$ & -1.32 & 5.7 & -0.98 & 14.2 & -0.66 & 29.4 \\
\hline Bulgaria & -0.94 & 15.6 & 0.16 & 63.5 & 0.14 & 60.2 \\
\hline Croatia & -0.06 & 57.3 & 0.35 & 66.4 & 0.52 & 69.7 \\
\hline
\end{tabular}




\begin{tabular}{|l|c|c|c|c|c|c|}
\hline \multirow{2}{*}{} & \multicolumn{2}{|c|}{1996} & \multicolumn{2}{c|}{ 2002 } & \multicolumn{2}{c|}{ 2006 } \\
\cline { 2 - 7 } & Score* & Rating** & Score* & Rating** & Score* & Rating** \\
\hline Macedonia & -0.34 & 43.6 & -0.48 & 35.5 & -0.20 & 48.3 \\
\hline Moldova & -0.56 & 32.2 & -0.62 & 29.4 & -0.85 & 22.3 \\
\hline Romania & -0.69 & 23.7 & -0.22 & 51.2 & -0.05 & 53.6 \\
\hline Serbia & -0.45 & 36.0 & -0.59 & 31.8 & -0.29 & 44.5 \\
\hline
\end{tabular}

Source: Kaufmann et al. (2007)

* and **-see Table 1

Observing government efficiency, it can be noticed that the situation is much better when compared to political stability. Croatia (0.52) and Bulgaria (0.14) achieved the best results in the region in 2006, while other countries recorded negative results: Romania (-0.05), Macedonia (-0.20), Serbia (-0.29), Albania (-0.42), Bosnia and Herzegovina (-0.66) and Moldova (-0.85), the latter being in last place in the region.

Following the development of countries in the region in the 1996-2006 period, Bulgaria achieved the best improvements in government efficiency in the region; it improved its 1996 score $(-0.94)$ by 1.08 and recorded in 2006a score of 0.14 . Bosnia and Herzegovina achieved a significant improvement of 0.66, although in 1996 it had the starting point of the worst result (-1.32) for the south-east Europe region during the entire decade. Romania improved its governmental efficiency by 0.64 in the period (from - 0.69 to -0.05 ); it did not change its position compared to Bulgaria, but it did change position compared to other countries in the region.

The good results that Bulgaria and Romania achieved in governmental efficiency are the consequence of reforms in the state administration, which was one of the conditions of their joining the EU. Croatia and Macedonia have also implemented significant reforms in their state administrations. Serbia has adopted a strategy of the reform of the administration in order to reduce the influence of politics on employees in the state administration, to improve administrative capacities and to adopt international and European standards, which are crucial in the process of European integration.

\section{Legislative quality in the south-east Europe region}

The indicator of legislative quality (administrative obstacles) describes the burden of legislation in the branches of trade and business and in the development of companies, and it also includes measures that do not contribute to the development of markets, such as the control of prices, the inadequate supervision of banks, etc. Table 4 provides figures on the quality of the legislation which has been achieved in the southeast European region. 
Table 4 - Quality of legislation in south-east Europe

\begin{tabular}{|l|c|c|c|c|c|c|}
\hline \multirow{2}{*}{} & \multicolumn{2}{|c|}{1996} & \multicolumn{2}{c|}{ 2002 } & \multicolumn{2}{c|}{ 2006 } \\
\cline { 2 - 7 } & Score* & Rating** & Score* & Rating** & Score* $^{*}$ & Rating** $^{*}$ \\
\hline Albania & 0.11 & 47.3 & -0.25 & 43.4 & -0.14 & 48.8 \\
\hline $\begin{array}{l}\text { Bosnia and } \\
\text { Herzegovina }\end{array}$ & -0.63 & 23.9 & -0.59 & 29.8 & -0.44 & 34.6 \\
\hline Bulgaria & 0.22 & 54.6 & 0.56 & 67.8 & 0.54 & 66.3 \\
\hline Croatia & 0.23 & 55.6 & 0.30 & 62.4 & 0.35 & 61.5 \\
\hline Macedonia & -0.18 & 35.6 & -0.15 & 46.8 & -0.06 & 52.7 \\
\hline Moldova & 0.17 & 49.8 & -0.44 & 35.6 & -0.36 & 41.5 \\
\hline Romania & -0.24 & 33.2 & 0.03 & 54.6 & 0.37 & 62.0 \\
\hline Serbia & -1.28 & 11.2 & -0.61 & 28.3 & -0.37 & 40.5 \\
\hline
\end{tabular}

Source: Kaufmann et al. (2007)

*and **-see Table 1

When we examine the development of legislation in south-east European countries in the 1996-2006 period, we can see that most countries improved this area of operation, except Albania and Moldova. Serbia and Romania achieved the biggest improvements: Serbia achieved a significant growth of 0.91 in the quality of its legislation (from -1.28 to -0.37); while Romania achieved growth of 0.51 , describing a path from a score of -0.24 to one of 0.37 . Bulgaria also recorded an improvement, going from 0.22 to 0.54 (growth of 0.32 ), while Croatia and Macedonia recorded small growths of 0.13 and 0.12 respectively.

Compared to 1996, the average rating of the south-east Europe region recorded in 2006 an improvement: from being better than $31.9 \%$ of countries concerning the quality of its legislation to being better than $48.6 \%$. Compared to other countries in the region, Moldova is significantly lagging with a figure of $41.5 \%$, lower than its 1996 rating of $49.8 \%$; Serbia, with a rating of $40.5 \%$, achieved multiple improvements in this component of administration: in 1996, it occupied a very low position, being better in this area than just $11.2 \%$ of other countries (the lowest rating in the region).

This indicator can be complemented with the database of the World Bank Doing Business $^{8}$ from 2004, where it is possible to find results on average procedures for founding companies, the minimum length of time involved and the lowest costs for company registration, such that investors could have a more clear picture about the

8 Doing Business is a database that analyses (for 175 countries) the different procedures (founding a company, providing permits, paying taxes, complying with investor protection requirements, contract protection, credit, company closures, etc.) which provide detailed information about the business and investment climate in a certain country. 
business climate in a certain country. Procedures cover requests for future taxes for employees, satisfying environmental criteria and other conditions that the founders of a company must fulfil in order to set up a business.

Table 5 provides a ranking for the countries of south-east Europe regarding the number of procedures that must be complied with, the number of days these can be expected to take and the costs of founding a company in the region.

Table 5 - Ranking of south-east European countries in procedures regarding the setting up of a company

\begin{tabular}{|l|c|c|c|c|}
\hline & Ranking & $\begin{array}{c}\text { No. of } \\
\text { procedures }\end{array}$ & $\begin{array}{c}\text { Duration } \\
\text { (days) }\end{array}$ & $\begin{array}{c}\text { Costs (\% of GDP } \\
\text { per capita) }\end{array}$ \\
\hline Albania & 112 & 11 & 39 & 22.4 \\
\hline Bosnia and Herzegovina & 141 & 12 & 54 & 37.0 \\
\hline Bulgaria & 85 & 9 & 32 & 7.9 \\
\hline Montenegro & 83 & 15 & 24 & 6.6 \\
\hline Croatia & 124 & 10 & 45 & 12.0 \\
\hline Macedonia & 76 & 10 & 18 & 7.4 \\
\hline Moldova & 84 & 10 & 30 & 13.3 \\
\hline Romania & 7 & 5 & 11 & 4.4 \\
\hline Serbia & 60 & 10 & 18 & 10.2 \\
\hline
\end{tabular}

Source: World Bank Doing Business in 2007.

The rule of law in the south-east Europe region

The indicator of the rule of law indicates the level of respect for the rules of a certain society and it encompasses citizens' perceptions, investors and an analysis of the frequency of crime, the efficiency and predictability of the courts, the implementation of contracts, protection of property rights, etc. Table 6 provides data on the situation regarding the rule of law in south-east Europe.

Table 6 - Rule of law in south-east Europe

\begin{tabular}{|l|c|c|c|c|c|c|}
\hline \multirow{2}{*}{} & \multicolumn{2}{|c|}{1996} & \multicolumn{2}{c|}{ 2002 } & \multicolumn{2}{c|}{ 2006 } \\
\cline { 2 - 7 } & Score* & Rating** & Score* & Rating** $^{* *}$ & Score* $^{*}$ & Rating** $^{* *}$ \\
\hline Albania & -0.12 & 52.4 & -0.94 & 19.5 & -0.7 & 28.1 \\
\hline $\begin{array}{l}\text { Bosnia and } \\
\text { Herzegovina }\end{array}$ & -0.03 & 54.8 & -0.73 & 29.5 & -0.53 & 37.1 \\
\hline Bulgaria & -0.11 & 52.9 & -0.03 & 52.9 & -0.17 & 50.0 \\
\hline Croatia & -0.57 & 32.9 & 0.03 & 55.2 & -0.03 & 52.9 \\
\hline
\end{tabular}




\begin{tabular}{|l|c|c|c|c|c|c|}
\hline \multirow{2}{*}{} & \multicolumn{2}{|c|}{1996} & \multicolumn{2}{c|}{ 2002 } & \multicolumn{2}{c|}{ 2006 } \\
\cline { 2 - 7 } & Score* & Rating** & Score* & Rating** & Score* & Rating** \\
\hline Macedonia & -0.16 & 50.5 & -0.59 & 32.9 & -0.46 & 43.8 \\
\hline Moldova & 0.10 & 53.3 & -0.74 & 29 & -0.61 & 32.4 \\
\hline Romania & -0.16 & 51 & -0.25 & 48.1 & -0.16 & 50.5 \\
\hline Serbia & -0.99 & 15.7 & -0.9 & 20 & -0.59 & 35.2 \\
\hline
\end{tabular}

Source: Kaufmann et al. (2007)

*and $* *$ - see Table 1

Observing changes in the rule of law for the countries of south-east Europe in the 1996-2006 period, it is clear that only two countries have recorded an improvement (Croatia by 0.54 and Serbia by 0.40 ): Romania maintained the level of 1996 while other countries saw a weakening of the rule of law.

All the countries of the region recorded negative results regarding the rule of law for 2006: Croatia (-0.03), Romania (-0.16), Bulgaria (-0.17), Macedonia (-0.46), Bosnia and Herzegovina (-0.53), Serbia (-0.59), Moldova (-0.61) and Albania (-0.70).

Albania, in last position, saw a worsening in the rule of law by 0.58 . Bosnia and Herzegovina recorded a similar result, with its score falling back by 0.50 (from -0.24 to -0.74), while Moldova recorded the biggest fall of all, of 0.71 (from a score of 0.10 to one of - 0.61 ). Croatia, with a figure of $52.9 \%$, is the best in the region; Bulgaria recorded a solid performance, being better than $50 \%$ of other countries, similar to the $50.5 \%$ recorded for Romania, while Macedonia was better than $43.8 \%$ of other countries.

\section{Control of corruption in south-east Europe}

This indicator measures perceptions of corruption, the appearance of which can be defined as the 'misuse of official authority for personal benefit'. Corruption is the enemy of democracy because it demolishes the principle of legality, the legitimacy of institutions and the level playing field regulation of the market.

The presence of corruption indicates no respect for the law by the one who is corrupted or by the one who induces the corruption. Taking into consideration that 'corruption leaves no evidence', this dimension of state administration is the most difficult to measure.

There is more and more empirical proof of the negative influence of corruption on economic growth. There are clear channels through which corruption reduces economic growth: lower domestic and direct foreign investment; and the routing of state consumption into less efficient projects but which provide more opportunities for bribes, leading to the reduced productivity of public investments, etc.

Governments in the south-east European region have recognised the negative social and economic effects of corruption and have been obliged to intensify the fight 
against corruption. In supporting the anti-corruption initiatives of the Stability Pact for South-East Europe, ${ }^{9}$ they have been obliged to adopt international anti-corruption instruments, strengthen national legislation, support the integrity of business and stimulate the participation of civil society in the fight against corruption.

Most of the countries in the south-east European region have adopted comprehensive strategies for the fight against corruption, as well as action plans for their implementation. All of the countries have signed international conventions and the key conventions of the Council of Europe on corruption. Likewise, all of them, except Moldova and Montenegro, have signed the UN Convention against corruption. It is important to emphasise that Bulgaria has signed the OECD convention against bribery.

Table 7 provides data on the realised level of the control of corruption in the southeast Europe region.

Table 7 - Control of corruption in south-east Europe

\begin{tabular}{|l|c|c|c|c|c|c|}
\hline \multirow{2}{*}{} & \multicolumn{2}{|c|}{1996} & \multicolumn{2}{c|}{ 2002 } & \multicolumn{2}{c|}{ 2006 } \\
\cline { 2 - 7 } & Score* & Rating** & Score* & Rating** & Score* $^{*}$ & Rating** $^{*}$ \\
\hline Albania & 0.03 & 59.2 & -0.81 & 25.7 & -0.67 & 28.2 \\
\hline $\begin{array}{l}\text { Bosnia and } \\
\text { Herzegovina }\end{array}$ & -0.25 & 46.6 & -0.45 & 40.3 & -0.32 & 47.6 \\
\hline Bulgaria & -0.76 & 25.7 & -0.14 & 53.4 & -0.05 & 57.3 \\
\hline Croatia & -0.59 & 30.6 & 0.19 & 61.7 & -0.02 & 58.3 \\
\hline Macedonia & -1.05 & 10.7 & -0.76 & 28.6 & -0.37 & 43.7 \\
\hline Moldova & -0.26 & 46.1 & -0.91 & 20.9 & -0.65 & 30.1 \\
\hline Romania & -0.23 & 48.5 & -0.35 & 44.7 & -0.18 & 53.4 \\
\hline Serbia & -0.99 & 17.5 & -0.76 & 29.6 & -0.35 & 46.1 \\
\hline
\end{tabular}

Source: Kaufmann et al. (2007)

* and **-see Table 1

When we examine developments in the states of south-east Europe in the 1996-2006 period, we can see that there was an improvement in the control of corruption in Bulgaria, Croatia, Romania and Macedonia, whereas Serbia, Albania, Bosnia and Herzegovina and Moldova weakened in this dimension of state administration. The average rating of the region improved from $35.7 \%$ to $43.3 \%$.

In the control of corruption, as was the case concerning the rule of law, all countries in south-east Europe recorded negative scores: Croatia (-0.02); Bulgaria (-0.05); Romania (-0.18); Bosnia and Herzegovina (-0.32); Serbia (-0.35); Macedonia (-0.37); Moldova (-0.65); and Albania (-0.67).

9 Stability Pact Anti-Corruption Initiative (SPAI). 
Bulgaria, Macedonia and Serbia recorded the biggest positive change in the region. Bulgaria made the biggest improvement in its score, going from -0.76 to -0.05 (growth of 0.71 ), while Macedonia achieved a growth of 0.68 in its score (from -1.05 to -0.37 ) and Serbia achieved a positive change from -0.99 to -0.35 (growth of 0.64 ). In contrast, Albania was weakened the most in its control of corruption, seeing a deterioration in its score of 0.70 (going from 0.03 to -0.67 ).

Croatia, with a rating of $58.3 \%$, is the best placed country in the region; Bulgaria doubled its rating to $57.3 \%$; while Romania increased to $53.4 \%$. Bosnia and Herzegovina, with a rating of $47.6 \%$, recorded a small growth compared to $1996(46.6 \%)$ and it was still classified in the region's top half. Serbia, with a rating of $46.1 \%$, visibly improved its 1996 result (17.5\%); while Macedonia achieved a rating of $40.4 \%$, implying multiple improvements comparing to 1996 when it had a rating of just $10.7 \%$. Moldova was better than $30.1 \%$ of countries, although this was a deterioration on its 1996 position when it was better than 46.1\%. Albania significantly worsened its rating, from $59.2 \%$ in 1996 to $28.2 \%$ in 2006 .

\section{Conclusion}

There is a widely-accepted opinion that better administration provides higher economic growth as a result of a more efficient division of labour, productive investment, lower transaction costs and a faster implementation of social and economic policies. ${ }^{10}$

Generally, more advanced states have a more developed and a more educated society with developed civil and non-governmental organisations and institutions including the media, which are more capable of following, observing and criticising the activities of the public sector. Higher revenue also promotes the political participation of citizens and the constraint of the executive authority. ${ }^{11}$

The number of research studies that have sought to discover the additional factors which influence economic growth has been increasing from the beginning of the nineties. However, it is still not possible to declare which factors lead to differences in economic development and growth rate between countries. States and their institutions have been taking on a more important role in these studies.

The main role of the modern state in a democratic market economy is to provide fair and equal conditions and standards for everyone as the basis for the daily individual life and economic activities of individuals and legal subjects. The law is a major mechanism used by the state. The adoption and implementation of parliamentary acts, entrusted legislation and secondary legislation, and the subsequent examination of their impacts, are significant tasks of the modern state.

The government is obliged to provide a convenient business ambience in which the private sector can function. Establishing a dynamic and enterprising private sector requires the existence of a stable local and global macroeconomic environment, a suitable physical and social infrastructure and the existence of the rule of law.

10 UN Millennium Project - Report to the Secretary-General (2005).

11 Barro proved in his research in 1999 that economic growth supports the development of democratic and political institutions. 
The presence of appropriate rules and institutions that create a stable ambience for business and investment is necessary for the efficient functioning of the state and the stimulation of economic growth, while feather-bedding focuses on the re-direction of existing resources towards ruling elites and their close circles and neither stimulates productive activities nor economic growth.

Until recently, it was considered impossible to confirm empirically the hypothesis that the quality of state administration has an influence on economic growth due to the nature of the situation. With the passing of time, however, different organisations have created indicators that measure the quality elements of state administration. The World Bank, within its Institute, has the largest database researching the quality of state administration in the world; in fact, it analyses more than 200 countries and territories. In this research, which is published in the study Governance Matters, the World Bank measures six components of state administration: freedom of expression and responsibility; political stability and the non-existence of violence; government efficiency; legislative quality; the rule of law; and the control of corruption.

Analysing the data presented in the last Governance Matters study, the conclusion is that, despite a significant improvement in the analysed period, the south-east European region has a high level of political instability; the state administration is under political influence; there is a low level of the rule of law; there are huge administrative obstacles; and the already high-level of corruption is spreading. Observing the countries individually, Bulgaria and Romania, and then Croatia, achieved the highest individual scores; the other countries of the region have to make more serious and more efficient approaches to the reforms which are underway.

Governmental programmes indicate that there is a determined political will for the carrying out of these activities. Even so, most of the countries have the burden of the rapid adoption of a huge number of new laws that are only one side of the process; the implementation of laws is a much more complicated and slower business, representing the other, and more important, side of the process.

There are many recommendations on how to improve the present situation. The most important of these are to attract a higher quality of human capital into the state administration and the judiciary. This could be realised through education as well as through changes in the methods of personnel selection and in the criteria for promotion. It is also recommended that clearer regulations be defined as regards the responsibility of judges, state functionaries and officials; administrative obstacles to investment be reduced; more efficient sanctions introduced regarding corruption; and a higher level of participation by civil society secured. All these recommendations are impracticable if there is no political will and determination because the state, which has the authority, also has the biggest responsibility.

The accession of the countries of south-east Europe to the European Union is a strategic goal, so the pressure to fulfil the Copenhagen criteria should encourage the implementation of reforms and the promotion of the region in general in the evaluation of good governance indicators. The figures indicate that the countries which are already in the EU, such as Bulgaria and Romania, and the one closest to EU membership, Croatia, describe the most significant progress with the realised indicators of 'good governance' compared to the rest of the region. 


\section{References}

Aidt, T, J. Dutta and V. Sena (2005) Growth, Governance and Corruption in the Presence of Threshold Effects: Theory and Evidence CWPE 0540.

Agere, S (2000) Promoting Good Governance: Principles, Practices and Perspective Commonwealth Secretariat.

Bhargava, V (2005) The Cancer of Corruption, World Bank Global Issues Seminar Series.

Campos, N. F. (2000) Context is Everything: Measuring Institutional Change in Transition Economies Working Paper No. 2269, World Bank.

Campos, N. F. and F. Coricelli (2002) Growth in Transition: What We Know, What We Don't and What We Should Working Paper No. 470, William Davidson Institute.

Commission of the European Communities (2001) European Governance, A White Paper COM(2001)428 final, Brussels.

Commission of the European Communities (2003) Governance and Development Communication from the Commission to The Council, The European Parliament and The European Economic and Social Committee COM(2003)615 final, Brussels.

Hall, R. and C. I. Jones (1999) 'Why do some countries produce so much output per worker than others?' Quarterly Journal of Economics.

Hellman, J. S, G. Jones and D. Kaufmann (2000) Seize the State, Seize the Day State Capture, Corruption and Influence in Transition Working Paper No. 2444, World Bank.

Hellman, J. S, G. Jones, D. Kaufmann and M. Schankerman (2000) Measuring Governance, Corruption and State Capture: How Firms and Bureaucrats Shape the Business Environment in Transition Economies Policy Research Working Paper No. 2312, World Bank.

Huther, J and A. Shah (1998) Applying a Simple Measure of Good Governance to the Debate on Fiscal Decentralization Working Paper No. 1894, World Bank.

Kaufmann, D, A. Kraay and P. Zoido-Lobaton (1999a) Aggregating Governance Indicators Policy Research Working Paper No. 2195, World Bank.

Kaufmann, D, A. Kraay and P. Zoido-Lobaton (1999b) Governance Matters Policy Research Woking Paper No. 2196, World Bank.

Kaufmann, D, A. Kraay and P. Zoido-Lobaton (2002) Governance Matters II - Updated Indicators for 2000/01 Policy Research Working Paper No. 2772, World Bank.

Kaufmann, D, A. Kraay and M. Mastruzzi (2003) Governance Matters III: Governance Indicators for 1996, 1998, 2000 and 2002 World Bank. 
Kaufmann, D, A. Kraay and M. Mastruzzi (2006) Governance Matters V: Aggregate and Individual Governance Indicators for 1996-2005 Policy Research Working Paper, World Bank.

Kaufmann, D, A. Kraay and M. Mastruzzi (2007) Governance Matters VI: Aggregate and Individual Governance Indicators for 1996-2006 Policy Research Working Paper 4280, World Bank.

Kaufmann, D, A. Kraay and M. Mastruzzi (2005) Measuring Governance Using CrossCountry Perceptions Data World Bank.

Kaufmann, D and A. Kraay (2002) Growth without Governance Policy Research Working Paper 2928, World Bank.

Keefer, P (2004) A review of the political economy of governance: From property rights to voice Policy Research Working Paper No. 3315, World Bank.

Kovačević R (1999) International financial institutions Institute for foreign trade: Beograd.

Stiglitz, J. E (2004) Economy of public sector Faculty of Economy: Beograd.

Tanzi, V and H. Davoodi (1997) Corruption, Public Investment and Growth Working Paper No. 139, International Monetary Fund.

World Bank and the IMF (2006) Global Monitoring Report 2006, Millennium Development Goals: Strengthening Mutual Accountability, Aid, Trade and Governance.

World Bank (2006a) World Development Report 2007.

World Bank (2006b) Doing business in 2007 - How to Reform.

World Bank (2006c) A Decade of Measuring the Quality of Governance.

www.worldbank.org

www.imf.org

www.doingbusiness.org

www.undp.org

www.europa.eu.int

www.oecd.org 